\title{
Implementasi Kurikulum Tingkat Satuan Pendidikan(KTSP) Pada Mata Pelajaran Bahasa Arab
}

\author{
Nurkomariah \\ Dosen Jurusan Manajemen Pendidikan Islam, Fakultas Ilmu Agama \\ Islam, Universitas Islam Indragiri (UNISI) Tembilahan \\ Abstrak \\ KTSP bahasa Arab adalah sebuah kurikulum yang menekankan pada \\ kompetensi berbahasa yakni kompetensi menyimak, kompetensi ber- \\ bicara, kompetensi membaca dan kompetensi menulis. Untuk men- \\ capai kompetensi tersebut guru bahasa Arab dituntut untuk dapat \\ menciptakan lingkungan Pembelajaran yang Aktif, Kreatif, Efektif \\ dan Menyenangkan (PAKEM) dengan didukung penggunaan media, \\ metode, serta pemilihan materi dan alat evaluasi yang tepat.
}

Key words: Implementasi, KTSP, Bahasa Arab.

\section{A. Pendahuluan}

Pemerintah pusat dalam hal ini Departemen Pendidikan Nasional (DEPDIKNAS) masih dipandang terlalu invensi dalam pengembangan kurikulum. Oleh Karena itu, dalam KTSP beban siswa sedikit berkurang dan tingkat satuan pendidikan (sekolah, guru, dan komite sekolah) diberikan kewenangan untuk mengembangkan kurikulum, seperti membuat indikator, silabus dan beberapa komponen kurikulum lainnya.

Lahirnya KTSP di sekolah diharapkan mampu mengembangkan potensi yang ada di daerahnya masing-masing, merencanakan kegiatan belajar dan mengajar sendiri dengan membuat indikator, materi pembelajaran, media serta metode pembelajaran sesuai dengan kemampuan dan kebutuhan anak didik dengan tetap mengacu kepada standar isi, proses, kompetensi lulusan, pembiayaan, sarana prasarana, pengelolaan, tenaga kependidikan, dan penilaian. Dengan adanya KTSP guru diharapkan bisa mengekplorasikan kemampuanya melalui penciptaan lingkungan belajar dan mengajar yang aktif, kreatif, efektif dan menyenangkan. Diantara kebijakan lain yang ada di dalam KTSP yakni adanya otonomi terhadap mata pelajaran bahasa Arab dari mata pelajaran Pendidikan Agama Islam (PAI). 
Dengan adanya otonomi ini guru diharapkan bisa mengembangkan pelajaran bahasa Arab melalui Rencana Pelaksanaan Pembelajaran (RPP) kemudian diimplementasikan dalam kegiatan belajar dan mengajar. ${ }^{1}$ Guru bahasa Arab diharapkan tidak hanya mengajarkan bahasa Arab sebagai konsep yang mengajarkan kaidah-kaidah bahasa tanpa menekankan kompetensi kebahasan.

Bahasa Arab adalah sebuah bahasa Semitik yang muncul dari daerah yang sekarang termasuk wilayah Arab Saudi. Bahasa ini adalah sebuah bahasa yang terbesar dari segi jumlah penutur dalam keluarga bahasa Semitik. Bahasa ini berkerabat dekat dengan bahasa Ibrani dan bahasa Aram. ${ }^{2}$

Bahasa Arab merupakan salah satu bahasa yang harus dipelajari khususnya bagi orang muslim, karena dengan memahami bahasa Arab orang muslim akan memahami isi Al-Qur'an, Hadis dan amalan-amalan ibadah lainnya seperti shalat dan doa. Selain bahasa Arab sebagai bahasa Al-Qur'an bahasa Arab juga merupakan bahasa internasional yang berfungsi sebagai alat komunikasi. Sebagai alat komunikasi, terdapat beberapa kompetensi yang harus dikuasai anak didik dalam kegiatan belajar dan mengajar bahasa Asing khususnya bahasa Arab yakni kompetensi menyimak, kompetensi berbicara, kompetensi membaca dan kompetensi menulis.

Perubahan kurikulum dari KBK kedalam KTSP merupakan salah satu bentuk usaha yang dilakukan oleh pemerintah untuk memecahkan persoalan pendidikan di Indonesia, akan tetapi dalam pelaksanaannya masih saja ditemukan kelemahan dan kekurangan dalam penyelenggaraan pendidikan, baik di tingkat Sekolah Dasar (SD), Sekolah Menengah Pertama (SMP), Sekolah Menengah Atas (SMA) maupun dijenjang Pendidikan Tinggi. Salah satu kekurangan atau kelemahan yang mendasar terlihat pada implementasi kurikulum, dimana guru merupakan implementator kurikulum, hal ini mengindikasikan bahwa kemampuan dan keterampilan guru selaku implementator kurikulum dianggap belum maksimal dan masih

1 Jauhar Ali, "Pembelajaran Bahasa Arab Berbasis Cross Cultural Understanding", http://www. joebukan.blogspot.com. pembelajaran-bahasa-arab-berbasiscross.html

2 Devita Rahmawati, "Metode Pembelajaran Bahasa Asing," http://www. devitarahmawati.blogspot.com/2012/01/metode-pembelajaran-bahasa-asing.html 
perlu ditingkatkan agar mereka dapat mengembangkan tugas dan tanggung jawab selaku implementator kurikulum yang baik.

\section{B. PEMBAHASAN}

a) Implementasi KTSP pada Mata Pelajaran Bahasa Arab

1) KTSP Sebagai Inovasi Kurikulum

Salah satu komponen dalam pendidikan adalah kurikulum. Kurikulum merupakan pedoman mendasar dalam proses pembelajaran. Keberhasilan dan kegagalan suatu proses pendidikan bergantung pada kurikulum yang digunakan, jika kurikulum didesain dengan baik, sistematis, komprehensif, dan integral dengan segala kebutuhan pengembangan dan pembelajaran anak didik untuk mempersiapkan diri menghadapi kehidupannya, tentu hasil atau output pendidikan akan mampu mewujudkan tujuan pendidikan.

Sesuai dengan sifatnya yang dinamis, para pengembang kurikulum senantiasa melakukan inovasi kurikulum, hal ini dimaksudkan guna meningkatkan mutu pendidikan sesuai dengan kemajuan peradaban terbukti dengan adanya kurikulum Tahun 1962, 1968, 1975, 1984, 1994, 2004, dan 2006 yang dikenal dengan Kurikulum Tingkat Satuan Pendidikan (KTSP).

Perubahan kurikulum atau disebut juga dengan inovasi kurikulum merupakan suatu pembaharuan atau gagasan yang diharapkan membawa dampak terhadap kurikulum itu sendiri. Menurut M. Asrori Ardiansyah, inovasi kurikulum adalah suatu gagasan atau praktek kurikulum baru dengan mengadopsi bagian-bagian yang potensial dari kurikulum tersebut dengan tujuan untuk memecahkan masalah atau mencapai tujuan tertentu." ${ }^{3}$ Adapun menurut Wina Sanjaya bahwa inovasi kurikulum adalah suatu ide, gagasan atau tindakan-tindakan tertentu dalam bidang kurikulum dan pembelajaran yang dianggap baru untuk memecahkan masalah pendidikan."

Berdasarkan beberapa pengertian di atas dapat penulis fahami bahwa inovasi kurikulum adalah sesuatu yang baru baik itu berupa ide maupun tindakan yang berhubungan dengan kurikulum untuk pemecahan suatu masalah. KTSP merupakan hasil inovasi dari

3 M. Asrori Ardiansyah, "Konsep Inovasi Kurikulum”, http://www.kabar-pendidikan.blogspot.com. konsep-inovasi-kurikulum.html

4 Wina Sanjaya, Kurikulum dan Pembelajaran (Jakarta: Kencana, 2008), hal. 317. 
KBK, perubahan KBK ke dalam KTSP telah ditetapkan dalam UU No. 20 Tahun 2003 tentang Sistem Pendidikan Nasional dan PP No.19 Tahun 2005 tentang Standar Nasional Pendidikan, mulai Tahun ajaran 2006/2007, KBK telah disempurnakan menjadi KTSP. ${ }^{5}$ Perubahan kurikulum merupakan hal yang harus dilakukan sejalan dengan perubahan yang terjadi di masyarakat. Kurikulum sekolah selalu mengikuti perubahan zaman, sebab jika tidak dilakukan perubahan maka pendidikan tidak dapat menghasilkan generasi yang tanggap terhadap perkembangan.

Adapun diantara bentuk inovasi pada KTSP Bahasa Arab adalah pada dokumen kurikulum, pada KBK untuk setiap pelajaran hanya memuat pendahuluan yang meliputi: rasional, pengertian, fungsi dan tujuan, ruang lingkup mata pelajaran, Standar Kompetensi (SK), Kompetensi Dasar (KD), dan materi pokok. Sementara dalam KTSP setiap mata pelajaran hanya dicantumkan: latar belakang, tujuan, ruang lingkup, SK dan KD, silabus KBK/KTSP. ${ }^{6}$ Selain itu bentuk inovasi lain pada KTSP adalah pelajaran bahasa arab telah berdiri sendiri dengan pelajaran PAI. ${ }^{7}$ Di dalam KTSP pelajaran bahasa Arab sebagaimana pelajaran bahasa Asing lainnya seperti bahasa Inggris dan Jepang yaitu mengembangkan keterampilan berkomunikasi lisan dan tulisan untuk memahami dan mengungkapkan informasi, pikiran, perasaan, serta mengembangkan ilmu pengetahuan, teknologi dan budaya. Karena bahasa Arab sesuai dengan fungsinya sebagai alat untuk menyampaikan dan menyerap gagasan-gagasan, pikiran, pendapat, dan perasaan baik secara lisan, maupun tulisan.

2) KTSP Sebagai Dokumen Kurikulum

Kurikulum selain sebagai implementasi, kurikulum juga sebagai dokumen. Kurikulum sebagai dokumen merupakan kurikulum tertulis yang dijadikan pedoman bagi setiap guru sekaligus pengem-

5 M. Asrori Ardiansyah, Op. Cit., hal.

6 Devita Rahmawati, "Metode Pembelajaran Bahasa Asing," http://www. devitarahmawati.blogspot.com/2012/01/metode-pembelajaran-bahasa-asing.html

7 Jauhar Ali, "Pembelajaran Bahasa Arab Berbasis Cross Cultural Understanding", http://www. joebukan.blogspot.com. pembelajaran-bahasa-arab-berbasiscross.html 
bang kurikulum. Secara dokumentatif, komponen KTSP dikemas dalam dua dokumen.

1. Struktur KTSP Dokumen Satu

Dokumen satu terdiri atas empat unsur, yaitu pendahuluan, tujuan pendidikan, struktur dan muatan kurikulum, dan kalender pendidikan.

a. Pada komponen pendahuluan terdiri atas latar belakang, tujuan, dan prinsip-prinsip pengembangan KTSP.

1) Latar belakang. Berisi tentang alasan-alasan pentingnya menerapkan KTSP.

2) Tujuan pengembangan dan fungsi KTSP. Tujuan pengembangan KTSP adalah untuk menjawab apa kegunaan dan fungsi KTSP untuk setiap orang yang terlibat dalam proses pendidikan khususnya guru. ${ }^{8}$

3) Prinsip pengembangan KTSP. Prinsip-prinsip pengembangan KTSP disesuaikan dengan aturan dan kebijakan yang telah ditentukan, yakni berpusat pada potensi, perkembangan, kebutuhan, dan kepentingan peserta didik dan lingkungannya, beragam dan terpadu, tanggap terhadap perkembangan ilmu pengetahuan, teknologi dan seni, relevan dengan kebutuhan kehidupan, menyeluruh dan berkesinambungan, belajar sepanjang hayat, seimbang antara kepentingan nasional dan kepentingan daerah.

b. Tujuan pendidikan

1) Tujuan pendidikan

Tujuan pendidikan dirumuskan berdasarkan undang-undang no 20 tahun 2003 pasal 3, yakni:

Untuk berkembangnya potensi peserta didik, agar menjadi manusia yang beriman dan bertaqwa kepada Tuhan Yang Maha Esa, berakhlaq mulia, sehat, berilmu, cakap, kreatif, mandiri, dan menjadi warga negara yang demokratis serta bertanggung jawab. ${ }^{9}$

Disamping tujuan pendidikan yang telah ditetapkan secara nasional tujuan pendidikan juga ditetapkan berdasarkan kebutuhan dan kondisi masing-masing sekolah.

8 Wina Sanjaya, Op. Cit., hal. 154.

9 Ibid., hal. 154-155. 
2) Visi dan misi sekolah

Visi adalah sasaran yang dirumuskan oleh berbagai komponen sekolah yang dapat dijangkau. Visi menjawab apa yang ingin dicapai oleh sekolah. ${ }^{10}$ Sementara misi adalah berkenaan dengan pertanyaan upaya apa yang dapat dilakukan untuk mencapai visi sekolah. ${ }^{11}$

c. Struktur dan muatan kurikulum.

Struktur kurikulum merupakan pola dan susunan mata pelajaran yang harus ditempuh oleh peserta didik dalam kegiatan pembelajaran.

d. Kalender pendidikan

Menurut Suryo Subroto kalender pendidikan adalah pengaturan waktu atau kegiatan sekolah baik kurikuler maupun ekstrakurikuler. ${ }^{12}$ Kalender pendidikan disusun oleh satuan pendidikan masing-masing dengan memperhatikan kebutuhan daerah, karakteristik sekolah, kebutuhan peserta didik dan masyarakat dengan mengacu pada ketentuan yang ditetapkan dalam standar isi.

2. Srtuktur Dokumen Dua

Dokumen II berisi tentang Silabus dan Rencana Pelaksanaan Pembelajaran (RPP).

a. Silabus

Silabus adalah rencana pembelajaran pada suatu kelompok mata pelajaran dengan tema tertentu, yang mencakup standar kompetensi, kompetensi dasar, materi pokok, kegiatan pembelajaran, indikator pencapaian kompetensi, penilaian, alokasi waktu dan sumber belajar yang dikembangkan oleh setiap satuan pendidikan, berdasarkan Standar Nasional Pendidikan..$^{13}$

Silabus disusun secara sistematis dan berisi komponenkomponen yang saling berkaitan, komponen-komponen

10 Ibid.,hal. 155.

11 Ibid.Hal. 157.

12 Suryo Subroto, Tata Laksana Kurikulum (Jakarta: Rineka Cipta, 2005), hal. 31.

13 Mulyasa, Implementasi Kurikulum Tingkat Satuan Pendidikan (Jakarta: Bumi Aksara, 2009), hal. 132. 
dalam silabus dimaksudkan agar terpenuhinya target pencapaian Kompetensi Dasar (KD). Adapun komponen-komponen silabus sebagaimana disebutkan oleh Mulyasa adalah terdiri atas identitas, Standar Kompetensi (SK), Kompetensi Dasar (KD), materi pembelajaran (materi pokok), indikator pencapaian kompetensi, penilaian, alokasi waktu, dan sumber belajar. ${ }^{14}$

Nama Sekolah

Mata Pelajaran

Kelas / Program

Semester

Standar Kompetensi

\section{Tabel I: Silabus ${ }^{15}$}

\begin{tabular}{|c|c|c|c|c|c|c|}
\hline 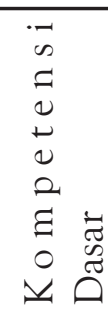 & 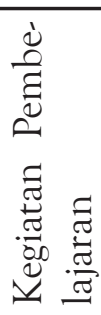 & 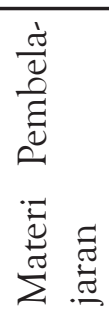 & 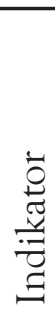 & 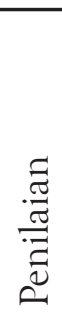 & 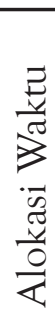 & 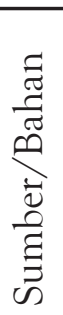 \\
\hline & & & & & & \\
\hline & & & & & & \\
\hline & & & & & & \\
\hline
\end{tabular}

b. Rencana Pelaksanaan Pembelajaran (RPP)

Rencana Pelaksanaan Pembelajaran (RPP) adalah rancangan pembelajaran mata pelajaran yang akan diterapkan guru dalam pembelajaran di kelas. ${ }^{16}$ Sementara itu Wina Sanjaya juga memberikan pengertian bahwa Rencana Pelaksanaan Pembelajaran (RPP) adalah program perencanaan yang disusun sebagai pedoman pelaksanaan pembelajaran

14 Ibid, hal. 135.

15 Ibid. hal. 192.

16 Mansur Muslich, KTSP (Dasar Pemahaman dan Pengembangan) (Jakarta: Bumi Aksara, 2008), hal. 45. 
untuk setiap kegiatan proses pembelajaran. ${ }^{17}$

Berdasarkan beberapa pengertian di atas dapat penulis simpulkan bahwa yang dimaksud RPP adalah rancangan pembelajaran guru yang telah disusun sebagai pedoman dalam kegiatan belajar dan mengajar. Adapun komponen RPP adalah sebagai berikut:identitas mata pelajaran, SK, $\mathrm{KD}$, indikator pencapaian komptensi, tujuan pembelajaran, materi pelajaran, metode pembelajaran, kegiatan pembelajaran, penilaian hasil belajar dan sumber belajar. ${ }^{18}$

Berikut ini langkah-langkah dari penyusunan RPP:

1) Mencantumkan Identitas.

Pencantuman identitas terdiri dari: nama sekolah, mata pelajaran, kelas, semester, SK, KD, indikator dan alokasi waktu. Hal yang perlu diperhatikan adalah: RPP boleh disusun untuk satu KD, SK, dan indikator dikutip dari silabus. (SK, KD, Indikator adalah suatu alur pikir yang saling terkait tidak dapat dipisahkan).

Alokasi waktu diperhitungkan untuk pencapaian satu KD dinyatakan dalam jam pelajaran dan banyaknya pertemuan. Karena itu waktu untuk mencapai suatu KD dapat diperhitungkan dalam satu atau beberapa kali pertemuan bergantung pada kompetensi dasarnya.

2) Merumuskan Tujuan Pembelajaran.

Tujuan pembelajaran dirumuskan berupa output (hasil langsung) dari satu paket kegiatan pembelajaran. Tujuan pembelajaran, boleh salah satu atau keseluruhan tujuan pembelajaran. Bila pembelajaran dilakukan lebih dari satu pertemuan, ada baiknya tujuan pembelajaran juga dibedakan menurut waktu pertemuan, sehingga setiap pertemuan dapat memberikan hasil.

3) Menetukan Materi Pembelajaran.

Untuk memudahkan penetapan materi pembelajaran, dapat diacu dari indikator.

17 Wina Sanjaya, Op. Cit., hal. 173.

18 Tirman, "Pengembangan RPP" diupload pada tanggal 14 september 2013 http://tirman.wordpress.com/pengembangan-rpp/html 
4) Menentukan Metode Pembelajaran.

Metode dapat diartikan benar-benar sebagai metode seperti metode ceramah, qira'ah, qawa'id wa tarjamah, diskusi dan hiwar, tetapi dapat pula diartikan sebagai model atau pendekatan pembelajaran seperti pendekatan proses, kontekstual, pemecahan masalah, bergantung pada karakteristik pendekatan atau strategi yang dipilih.

5) Menetapkan Kegiatan Pembelajaran

a) Kegiatan pendahuluan

Dalam kegiatan pendahuluan, guru menyiapkan siswa secara psikis dan fisik untuk mengikuti proses pembelajaran, mengajukan pertanyaan-pertanyaan yang mengaitkan pengetahuan sebelumnya dengan materi yang akan dipelajari, menjelaskan tujuan pembelajaran atau kompetensi dasar yang akan dicapai.

b) Kegiatan inti

Kegiatan inti merupakan proses pembelajaran untuk mencapai KD. Kegiatan pembelajaran dilakukan secara interaktif, inspiratif, menyenangkan, menantang, memotivasi peserta didik untuk berpartisipasi aktif, dan memberikan ruang cukup bagi prakarsa, kreativitas, dan kemandirian sesuai dengan bakat, minat, dan perkembangan fisik serta psikologis peserta didik. Kegiatan ini dilakukan secara sistematis dan sistemik melalui proses eksplorasi, elaborasi, dan konfirmasi.

c) Kegiatan penutup

Untuk kegiatan penutup pada mata pelajaran bahasa Arab guru bisa dengan mengarahkan peserta didik untuk membuat rangkuman atau kesimpulan, guru memeriksa hasil belajar peserta didik dengan memberikan tes menyimak, tes membaca, tes tertulis, tes lisan atau meminta peserta didik untuk mengulang kembali kesimpulan yang telah disusun atau dalam bentuk tanya jawab dengan mengambil beberapa peserta didik sebagai sampelnya.

6) Memilih Sumber Belajar

Pemilihan sumber belajar mengacu pada perumusan yang 
ada dalam silabus yang dikembangkan. Sumber belajar dituliskan secara lebih operasional dan bisa langsung disebutkan bahan ajar apa yang digunakan.

7) Menentukan Penilaian

Prosedur dan instrumen penilaian proses dan hasil belajar disesuaikan dengan indikator pencapaian kompetensi dan mengacu pada Standar Penilaian. Berikut ini contoh format RPP.

Rencana Pelaksanaan Pembelajaran (RPP) ${ }^{19}$

Satuan Pendidikan

Mata Pelajaran

Kelas/Semester

Standar Kompetensi

Kompetensi Dasar

Indikator

Alokasi waktu

: ... X ... menit ( ... pertemuan)

a. Tujuan Pembelajaran

b. Materi Pembelajaran

c. Metode Pembelajaran

d. Langkah-Langkah Kegiatan Pembelajaran .

Pertemuan I

Kegiatan awal

: (dilengkapi dengan alokasi waktu)

Kegiatan inti

: (dilengkapi dengan alokasi waktu)

Kegiatan Penutup

: (dilengkapi dengan alokasi waktu)

Pertemuan II

dan seterusnya.

e. Sumber Belajar

f. Penilaian

Teknik

Bentuk instrumen

Contoh instrumen (soal/tugas)

disertai kunci jawaban atau pedoman penilaian.

Mengetahui

Kepala Sekolah

Guru Mata Pelajaran

19 Mansur Muslich, KTSP (Dasar Pemahaman dan Pengembangan), hal. 47. 
RPP sangat penting kedudukanya baik guru yang sudah berpengalaman maupun guru baru. Hal ini dikarenakan guru tidak hanya berkewajiban menyampaikan materi pembelajaran saja, akan tetapi guru harus mampu menciptakan lingkungan pembelajaran yang aktif, kreatif, efektif dan menyenangkan. Selain itu kondisi siswa masa sekarang dan masa akan datang tidaklah sama, karena itulah RPP sangat diperlukan bagi guru yang melaksanakan tugasnya sebagai pendidik. RPP akan memudahkan guru dalam mencapai tujuan pembelajaran.

\section{3) KTSP Bahasa Arab}

KTSP merupakan KBK yang disempurnakan. KTSP sebagai kurikulum terbaru menargetkan pada suatu kompetensi yang seharusnya dimiliki oleh siswa. Kompetensi diartikan sebagai pengetahuan, sikap, dan keterampilan yang dapat didemonstrasikan, ditunjukkan atau ditampilkan oleh siswa sebagai hasil belajar. ${ }^{20}$ Di antara karakteristik KTSP bahasa Arab adalah:

1. Adanya pemberian otonomi luas kepada sekolah atau satuan pendidikan. Yakni dengan adanya pemberian kewenangan dan kekuasaan yang luas untuk mengembangkan pembelajaran sesuai dengan kondisi dan kebutuhan peserta didik serta tuntutan masyarakat. Selain itu, sekolah diberi kewenangan untuk menggali dan mengelola sumber dana sesuai dengan prioritas kebutuhan.

2. Partisipasi masyarakat dan orang tua yang tinggi. Orang tua peserta didik dan masyarakat tidak hanya mendukung sekolah melalui bantuan keuangan, tetapi melalui komite sekolah dan dewan pendidikan merumuskan serta mengembangkan program-program yang dapat meningkatkan kualitas pembelajaran.

3. Kepemimpinan yang demokratis dan profesional. Pengembangan dan pelaksanaan KTSP didukung oleh adanya kepemimpinan sekolah yang demokratis dan profesional. Kepala sekolah dan guru-guru sebagai tenaga pelaksana kurikulum merupakan orang-orang yang memiliki kemampuan dan in-

20 Jauhar Ali, Op. Cit., hal. 
tegritas profesional. Dalam proses pengambilan keputusan, kepala sekolah mengimplementasikan proses bottom-up secara demokratis, sehingga semua pihak memiliki tanggung jawab terhadap keputusan yang diambil beserta pelaksanaannya.

4. Tim kerja yang kompak dan transparan. Semua yang terlibat dalam pelaksanaan pembelajaran adalah satu tim-kerja yang bekerja sama secara harmonis sesuai dengan posisinya masing-masing serta tidak saling menunjukkan kuasa atau paling berjasa. ${ }^{21}$

Di dalam KTSP pemerintah hanya memberikan rambu-rambu Standar Isi dan Standar Kelulusan. Adapun dalam Standar Kelulusan ada dua kompetensi yang diharapkan yaitu Standar Kompetensi (SK) dan Kompetensi Dasar (KD). Standar ini dipergunakan sebagai acuan dalam mengembangkan kurikulum bahasa Arab sesuai dengan kebutuhan daerah atau madrasah. Kemudian kurikulum bahasa Arab di madrasah dipersiapkan untuk pencapaian keterampilan dasar awal berbahasa Arab siswa, dengan didukung aspek-aspek kebahasaaan seperti mendengarkan (istima'), berbicara (kalam), membaca (qira'ah) dan menulis (kitabah).

Untuk pencapaian kompetensi di atas dirancang kegiatan pembelajaran bahasa Arab dengan tema-tema tentang kegiatan sehari-hari, seperti tentang aqidah dan ibadah. Disamping itu untuk mendukung tercapainnya kompetensi tersebut guru didorong untuk aktif mendesain silabus dan RPP sedemikian rupa dengan diberikannya kebebasan menggunakan berbagai macam metode serta media pembelajaran bahasa Arab guna tercapainya tujuan pembelajaran bahasa Arab. Sementara itu di dalam KTSP siswa didorong untuk secara aktif terlibat dalam kegiatan membaca, menulis, mengungkapkan pendapat, membandingkan dan mendiskusikan suatu teks juga dimotivasi untuk mempelajari dan mendalami sejumlah literatur yang dapat ditemui sehari-hari, baik berupa media cetak maupun elektronik. Dengan bekal sejumlah pengetahuan tersebut, mereka dapat mempelajari budayanya sendiri dan juga budaya lain. Mereka kemudian dapat menggunakan teks tersebut untuk mempelajari

21 Usman Alwin. "Karakteristik KTSP" diupload pada tanggal 16 september 2013 http://id.shvoong.com/social-sciences/education/2250517-karakteristikktsp/\#ixzz2MiqbSABY 
suatu konsep dan berpikir secara kritis mengenai dunia mereka dan komunitas global meliputi ilmu pengetahuan baik dibidang teknik, ekonomi, psikologi maupun seni yang bersumber dari buku-buku bahasa Arabdisamping sebagai sarana komunikasi dengan lingkungan sekitarnya.

Seiring perkembangan teknologi, bahasa Arab diharapkan dapat digunakan siswa untuk mengakses informasi dari berbagai sumber yang berbahasa Arab sekaligus mempresentasikan informasi dan gagasan secara sistematis dalam bentuk yang bervariasi, baik secara lisan maupun tulisan, tentang berbagai topik berbahasa Arab. Konsep pembelajaran bahasa Arab ini berimplikasi pada keterampilan siswa untuk berkomunikasi, tidak hanya untuk memahami teks-teks keagamaan saja tetapi dapat digunakan sebagai alat untuk berinteraksi sosial dalam situasi yang beragam dan latar belakang budaya yang berbeda. Adapun rambu-rambu yang ditetapkan dalam rumusan KTSP mata pelajaran bahasa Arab adalah sebagai berikut:

1. Menerapkan pendekatan kompetensi dengan pola pembelajaran yang dikembangkan menekankan keterpaduan antara tiga lingkungan pendidikan yaitu: lingkungan keluarga, madrasah, dan masyarakat.

2. Penerapan konsep-konsep pembelajaran bahasa Arab di madrasah adalah belajar menggunakan bahasa untuk berkomunikasi, baik lisan maupun tulisan, bukan untuk mendalami struktur kalimat itu sendiri.

3. Memanfaatkan teknologi komunikasi ini dapat berupa media cetak dan elektronika. Media cetak meliputi surat kabar, majalah, buku brosur, dan lain-lain. Sedangkan media elektronika meliputi komuter, televisi, radio internet, VCD, CD, dan lain-lain.

4. KTSP atau silabus dan RPP yang sudah disusun hanya sebagai model yang masih dapat dikembangkan atau disederhanakan sesuai dengan kondisi siswa. ${ }^{22}$

4) Implementasi KTSP Bahasa Arab

Implementasi KTSP adalah bagaimana menyampaikan pesanpesan kurikulum kepada peserta didik untuk membentuk kompe-

22 Jauhar Ali, Op. Cit., hal 
tensi mereka sesuai dengan karakteristik dan kemampuan masingmasing. ${ }^{23}$ Dalam implementasi KTSP bahasa Arab guru dituntut kemampuannya untuk dapat memberikan kemudahan-kemudahan belajar kepada peserta didik agar mampu berinteraksi dengan lingkungannya baik lingkungan sekolah, maupun lingkungan masyarakat. Dengan kemampuannya berinteraksi ini diharapkan adanya perubahan tingkah laku sebagaimana yang tertuang dalam Standar Isi dan Standar Kelulusan.

Berdasarkan pengertian di atas, penulis dapat menyimpulkan bahwa yang dimaksud dengan implementasi KTSP bahasa Arab adalah bagaimana menyampaikan pesan-pesan kurikulum bahasa Arab kepada peserta didik untuk membentuk kompetensi mereka sesuai dengan karakteristik dan kemampuan masing-masing peserta didik. Adapun kompetensi yang harus dimiliki anak didik dalam mempelajari bahasa Arab adalah kompetensi mendengar (mahaarah alistima'), kompetensi berbicara (mahaarah al-kalam), kompetensi membaca (mahaarah al-qiraah), dan kompetensi menulis (mahaarah al-kitabah).

5) Bahasa Arab Sebagai Mata Pelajaran

Sebagai alat komunikasi bahasa merupakan suatu alat yang sangat penting dalam kehidupan bersosial, dengan bahasa manusia dapat menyampaikan ide maupun pemikirannya. Karenanya bahasa menjadi sangat penting untuk dipelajari mulai dari tingkat Taman Kanak-Kanak (TK) sampai Perguruan Tinggi. Pentingnya belajar ini terbukti dengan adanya firman Allah sebagai berikut:

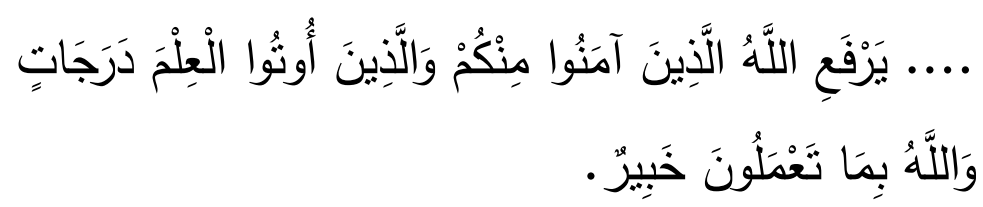

Allah akan orang-orang yang beriman di antaramu dan orang-orang yang diberi ilmu pengetahuan beberapa derajat (Q.S 58:11) ${ }^{24}$

Mengingat pentingnya mempelajari bahasa Arab maka seba-

23 Mulyasa, Op. Cit., hal. 178.

24 Departemen Agama RI, Al-Qur'an dan Terjemahnya,hal. 544. 
gian negara besar telah membuka universitas-universitas atau sekolah-sekolah yang mempelajari bahasa Arab. Hal ini sesuai dengan apa yang dituturkan oleh Abdul Aziz dalam bukunya Psikolinguistik Pembelajaran Bahasa Arab bahwa:

Pada akhir abad ke-13 atau 19M yang lalu, dan awal abad ke-14 atau 20M, program pengajaran bahasa Arab untuk non Arab telah dibuka di banyak universitas di negara-negara Arab, dipusat-pusat kegiatan Islam di lembaga-lembaga, di unit-unit khusus (independen), di jurusan-jurusan dalam fakultas sastra, atau fakultas-fakultas bahasa juga telah dibuka program-program pengajaran bahasa Arab yang diajarkan di beberapa jurusan studi bahasa Arab atau studi ketimuran di universitas-universitas Barat, Eropa, dan Amerika Serikat. ${ }^{25}$

Lembaga-lembaga pendidikan yang membuka kelas bahasa Arab ini tidak hanya menyiapkan lulusan-lulusan yang pandai bahasa Arab saja akan tetapi juga membuka kelas-kelas untuk para siswa yang ingin menjadi pengajar bahasa Arab dengan memberikan ijazah magister dan diploma selain pembekalan sebagai pendidik bahasa Arab. Hal ini sebagaimana diungkapkan oleh Abdul Aziz sebagai berikut: "... lembaga-lembaga tersebut juga memberikan ijazah magister dan diploma di bidang ini..." ${ }^{\prime 6}$

6) Komponen Kurikulum Bahasa Arab

a. Komponen Tujuan

Komponen tujuan merupakan komponen utama yang harus ditentukan dan dirumuskan sebelum merumuskan dan menentukan komponen lainnya. Menurut Lias Hasibuan bahwa:Tujuan kurikulum dapat dispesifikasikan ke dalam tujuan pembelajaran umum yaitu berupa tujuan yang ingin dicapai untuk satu semester, atau tujuan pembelajaran khusus yang menjadi target pada setiap kali tatap muka. ${ }^{27}$

Adapun kompetensi yang harus dimiliki oleh siswa dalam mempelajari bahasa Arab adalah kompetensi mendengar, kompetensi berbicara, kompetensi membaca dan kompetensi menulis. Hal ini

25 Abdul Aziz, Psikolinguistik Pembelajaran Bahasa Arab (Bandung: Humaniora, 2009), hal. 58.

26 Ibid.

27 Ibid. 
sebagaimana yang tercantum dalam peraturan Menteri Pendidikan Nasional Republik Indonesia Nomor 23 Tahun 2006 tentang Standar Kompetensi mata pelajaran bahasa Arab pada jenjang SMA atau MA adalah:

a. Mendengarkan. memahami huruf hijaiyah dan makna dalam wacana lisan berbentuk paparan dan dialog sederhana tentang identitas diri, kehidupan sekolah, kehidupan keluarga, kehidupan sehari-hari, hobi dan pekerjaan.

b. Berbicara. mengungkapkan makna secara lisan dalam wacana berbentuk paparan dan dialog sederhana tentang identitas diri, kehidupan sekolah, kehidupan keluarga, kehidupan sehari-hari, hobi dan pekerjaan.

c. Membaca. Melafalkan huruf hijaiyah dan memahami makna dalam wacana tertulis berbentuk paparan dan dialog sederhana tentang identitas diri, kehidupan sekolah, kehidupan keluarga, kehidupan sehari-hari, hobi dan pekerjaan.

d. Menulis. menulis huruf hijaiyah dan mengungkapkan makna secara tertulis dalam wacana berbentuk paparan dan dialog sederhana tentang identitas diri, kehidupan sekolah, kehidupan keluarga, kehidupan sehari-hari, hobi dan pekerjaan..$^{28}$

Dalam pembelajaran bahasa Arab, guru tidak hanya cukup dengan pengetahuan saja akan tetapi dituntut untuk dapat menciptakan lingkungan belajar yang aktif, kreatif, efektif dan menyenangkan. Dengan begitu diharapkan tujuan pembelajaran akan tercapai.

\section{b. Komponen Materi}

Komponen materi merupakan komponen yang tidak kalah pentingnya dengan komponen tujuan, karena yang dimaksud dengan materi adalah "bahan-bahan kajian yang terdiri dari ilmu pengetahuan, nilai, pengalaman, dan keterampilan yang dikembangkan ke dalam proses pembelajaran guna mencapai komponen tujuan." ${ }^{29}$ Berdasarkan pendapat di atas dapat difahami bahwa materi pelajaran bahasa Arab adalah sejumlah pengetahuan, baik itu pengetahuan

28 Departemen Pendidikan Nasional, Peraturan Menteri Pendidikan Nasional Republik Indonesia (Jakarta: Tp. 2006), hal. 60-61.

29 Lias Hasibuan, Kurikulum dan Pemikiran Pendidikan (Jakarta: Gaung Persada Press, 2010), hal. 39. 
tentang kognitif, afektif, dan psikomotor yang disusun secara sistematis dan ditujukan untuk pembelajaran bahasa Arab serta dapat digunakan guru dan murid sebagai bahan ajar dalam kegiatan belajar dan mengajar.

Sebagaimana yang telah disebutkan pada komponen tujuan bahwa tujuan dari pembelajaran bahasa Arab adalah untuk mencapai empat kompetensi yaitu kompetensi menyimak, kompetensi berbicara, kompetensi membaca dan kompetensi menulis, berdasarkan tujuan pembelajaran bahasa Arab itulah guru mengembangkan serta menentukan komponen materi bahasa Arab, yakni dengan mengacu kepada ke-empat mahaarah tersebut yang kemudian dikembangkan kepada indikator-indikator tertentu sesuai dengan materi yang akan disampaikan guru bahasa Arab.

c. Komponen Metode

Metode adalah segala hal yang termuat dalam setiap proses pengajaran yang memuat di dalamnya berbagai macam usaha, aturan, serta sarana dan gaya penyajian. ${ }^{30}$

Dalam penggunaan metode pembelajaran bahasa Arab guru harus menyesuaikan dengan materi serta topik yang akan disampaikan kepada anak didik, dengan penggunaan metode yang tepat siswa diharapkan dapat termotivasi dalam mengikuti pelajaran bahasa Arab. Pemilihan serta penggunaan metode juga perlu didukung oleh pemilihan serta pengguanaan media yang tepat sehingga memudahkan bagi guru dalam mencapai tujuan pembelajaran bahasa Arab. Adapun yang dimaksud dengan media pembelajaran sebagaimana dikutip dari Gerlach dan Ely oleh Abdul Wahab Rosyidibahwa pengertian media bisa dibagi kedalam dua pengertian yakni pengertian secara luas dan pengertian secara sempit adapun pengertian media secara luas adalah "setiap orang, materi, atau peristiwa yang memberikan kesempatan kepada siswa untuk memperoleh pengetahuan, keterampilan, dan sikap." ${ }^{31}$ Pengertian media pembelajaran dalam pengertian sempit adalah sarana non personal (bukan manusia) yang digunakan oleh guru yang memegang peranan dalam proses

30 Ibid., hal. 3

31 Abdul Wahab Rosyidi, Media Pembelajaran Bahasa Arab (Malang: UIN Malang Press, 2009), hal. 25. 


\section{$54 \frac{\text { Jurnal AL-AFKAR }}{\text { Vol. II, No. II, Oktober } 2013}$}

belajar mengajar untuk mencapai tujuan. ${ }^{32}$

Berdasarkan pengertian di atas penulis menyimpulkan bahwa media pembelajaran bahasa Arab adalah segala sesuatu yang bisa mengantarkan anak didik kepada pemahaman akan materi pembelajaran, baik itu berupa manusia seperti suara, isyarat, maupun non manusia seperti radio, tape recorder, papan tulis, kartu, gambar dan lain-lain. Di antara kriteria strategi pendayagunaan dan pengembangan media pembelajaran bahasa Arab, kontekstualitas, pemrograman, praktik dan pengalaman langsung, pemvariasian, dan pengembangan keterampilan proses. ${ }^{33}$

Selain media, yang tidak kalah pentingnya dalam menentukan keberhasilan dalam pembelajaran bahasa Arab adalah strategi pembelajaran bahasa Arab. Adapun yang dimaksud dengan strategi pembelajaran bahasa Arab adalah:

Sejumlah program atau rencana konseptual yang digunakansebagai acuan dalam melakukan kegiatan pembelajaran bahasa Arab agar pencapaian tujuan berlangsung sesuai dengan target yang diharapkan. $^{34}$

Berikut ini beberapa strategi dasar yang perlu diperhatikan dalam pembelajaran bahasa Arab:

(1) Mengidentifikasi dan menetapkan spesifikasi dan kualifikasi perubahan tingkah laku dan kepribadian anak didik sebagaimana yang diharapkan

(2) Memilih sistem pendekatan belajar mengajar berdasarkan aspirasi dan pandangan hidup masyarakat

(3) Memilih dan menetapkan prosedur, metode, dan teknik belajar mengajar yang dianggap paling tepat dan efektif

(4) Menetapkan norma-norma dan batas minimal keberhasilan atau kriteria standar keberhasilan sehingga dapat dijadikan pedoman oleh guru dalam melakukan evaluasi hasil kegiatan belajar mengajar selanjutnya. ${ }^{35}$

32 Ibid., hal. 26.

33 Muhbib Abdul Wahab, Epistemologi dan Metodologi Pembelajaran Bahasa Arab (Jakarta: UIN Syarif Hidayatullah, 2008), hal. 262-263.

34 Ibid., hal. 130.

35 Muhbib Abdul Wahab, Op. Cit., hal. 129. 
Berdasarkan beberapa pendapat di atas dapat diketahui bahwa strategi pembelajaran bahasa Arab adalah sejumlah rencana konseptual yang disusun terlebih dahulu sebelum guru bahasa Arab mengajar di kelas. Dalam hal ini guru menetapkan kompetensi yang harus dicapai oleh anak didik, memilih pendekatan yang digunakan, menetapkan prosedur, metode, dan teknik pembelajaran, serta menetapkan batas minimal yang harus dikuasai oleh anak didik, yang kesemuanya ini disusun dalam bentuk RPP.

d. Komponen Evaluasi

Dalam pembelajaran bahasa Arab terdapat empat komponen yang harus dimiliki oleh siswa yakni kompetensi menyimak, kompetensi berbicara, kompetensi membaca, dan kompetensi menulis. Untuk mengetahui ketercapaian siswa dalam mempelajari bahasa Arab maka perlu diadakan penilaian ke-empat komponen tersebut.

7) Faktor-Faktor Yang Mempengaruhi Implementasi KTSP Bahasa Arab

Terdapat beberapa faktor yang dapat mempengaruhi implementasi KTSP, hal ini sebagaimana diungkapkan oleh Oemar Hamalik bahwa faktor-faktor yang mempengaruhi implementasi KTSP adalah sebagai berikut:

(1) Karakteristik kurikulum, yang mencakup ruang lingkup bahan ajar, tujuan, fungsi, sifat dan sebagainya.

(2) Strategi implementasi, yaitu strategi yang digunakan dalam implementasi kurikulum, seperti diskusi profesi, seminar, penataran, lokakarya, penyediaan buku kurikulum, dan berbagai kegiatan lain yang dapat mendorong penggunaan kurikulum di lapangan.

(3) Karakteristik pengguna kurikulum, yang meliputi pengetahuan, keterampilan, serta nilai dan sikap guru terhadap kurikulum dalam pembelajaran. ${ }^{36}$

8) Upaya Peningkatan Implementasi KTSP Bahasa Arab

J.G Owen dalam Oemar Hamalik menyebutkan yang kemudian dikutip oleh Rino bahwa berdasarkan faktor-faktor yang

36 Oemar Hamalik, Dasar-dasar Pengembangan Kurikulum (Bandung: Remaja Rosdakarya, 2008), hal. 239.. 
dapat mempengaruhi implementasi KTSP, maka dapat ditentukan pendekatan yang digunakan dalam implementasi yang tepat yaitu: tipe perencanaan yang digunakan yaitu topdown dan grass-root, penggunaan strategi implementasi dan supervisi yang dilakukan oleh kepala sekolah dan guru. ${ }^{37}$

\section{b) Tipe Perencanaan yang Digunakan (Topdown dan Grass-Root)}

Pada pendekatan administratif, inisiatif pengembangan kurikulum berasal dari para pemegang kebijakan kemudian turun ke stafnya atau dari atas ke bawah (topdown), maka dalam model grass roots, inisiatif pengembangan kurikulum dimulai dari guru-guru sebagai implementator, kemudian menyebar pada lingkungan yang lebih luas (bottom up). Oleh karena sifatnya yang demikian, maka pendekatan ini lebih banyak digunakan dalam penyempurnaan kurikulum (curriculum improvement), walaupun dalam skala yang terbatas mungkin juga digunakan dalam pengembangan kurikulum baru (curriculum construction).

a) Penggunaan Strategi Implementasi KTSP .

Untuk mewujudkan implementasi KTSP yang efisien dan efektif perlu dikembangkan strategi khusus yangberorientasi pada guru, antara lain:

1. Mengubah mindset guru dari paradigma konvensional ke paradigm abad 21 (baru). Perubahan mindset ini seiring dengan paradigma pengelolaan pendidikan hari ini yaitu;

a) Dari sentralisasi ke desentralisasi,

b) Dari kebijakan yang top down ke kebijakan yang bottom up,

c) Dari orientasi pengembangan yang parsial ke orientasi pengembangan yang holistik,

d) Dari peran pemerintah yang dominan ke meningkatnya peran serta masyarakat secara kualitatif dan kuantitatif,

e) Dari lemahnya peran institusi non sekolah ke pemberdayaaninstitusi masyarakat,

f) Dari "birokrasi berlebihan" ke "debirokratisasi",

g) Dari "manajemen tertutup" (close management) ke "management terbuka" (open management),

37 Rino, "Strategi Implementasi KTSP" http://www.scribd.com/Strategi-Implementasi-Kurikulum-Tingkat-Satuan-Pendidikan.html. 
h) Dari pengembangan pendidikan "terbesar menjadi tanggung jawab pemerintah" berubah ke "sebagian besar menjadi tanggung jawab orang tua siswa dan masyarakat (stakeholders). ${ }^{38}$

2. Membentuk budaya (kultur) baru di lingkungan sekolah

Membangun budaya dalam kontek implementasi KTSP adalah sejumlahperilaku yang disepakati sebagai identitasdan karakteristik pada guru melalui kesepakatan bersama serta diiringi dengan sebuah komitmen yang tinggiuntuk melaksanakannya.

3. Guru sebagai pengembang kurikulum

Sebagai seorang pengembang kurikulum guru dituntut untuk memiliki pemahaman dan wawasan yang luas tentang kurikulum baik secara teoritis maupun secara praktis.

b) Support Activitas, Supervisi yang dilakukan oleh Kepala Sekolah dan Guru

Supervisi dilakukan oleh kepala sekolah bukan hanya untuk guru-guru atau pegawai dalam menjalankan tugas dengan sebaikbaiknya, tetapi kepala sekolah juga berusaha bersama guru-guru bagaimana cara memperbaiki proses belajar mengajar. Dalam kegiatan supervisi guru-guru tidak dianggap sebagai pelaksana pasif, melainkan sebagai partner yang mempunyai ide-ide dan pengalamanpengalaman yang perlu didengar, dihargai dan diikutsertakan di dalam usaha-usaha perbaikan pendidikan.

\section{Kesimpulan}

KTSP merupakan hasil inovasi dari KBK, Diantara bentuk inovasi pada KTSP Bahasa Arab adalah pada dokumen kurikulum, pada KBK untuk setiap pelajaran hanya memuat pendahuluan yang meliputi: rasional, pengertian, fungsi dan tujuan, ruang lingkup mata pelajaran, Standar Kompetensi (SK), Kompetensi Dasar (KD), dan materi pokok. Sementara dalam KTSP setiap mata pelajaran hanya dicantumkan: latar belakang, tujuan, ruang lingkup, SK dan KD, silabus KBK/KTSP.Pada KTSP pelajaran bahasa Arab telah berdiri sendiri dengan pelajaran PAI. Di dalam KTSP pelajaran bahasa Arab sebagaimana pelajaran bahasa Asing lainnya sep-

$38 \mathrm{Ibid}$ 
erti bahasa Inggris dan Jepang yaitu mengembangkan keterampilan berkomunikasi lisan dan tulisan untuk memahami dan mengungkapkan informasi, pikiran, perasaan, serta mengembangkan ilmu pengetahuan, teknologi dan budaya.

\section{Daftar Pustaka}

Abdul Aziz, Psikolinguistik Pembelajaran Bahasa Arab (Bandung: Humaniora, 2009)

Abdul Wahab Rosyidi, Media Pembelajaran Bahasa Arab (Malang: UIN Malang Press, 2009)

Departemen Agama RI, Al-Qur'an dan Terjemahnya.

Departemen Pendidikan Nasional, Peraturan Menteri Pendidikan Nasional Republik Indonesia (Jakarta: Tp. 2006)

Devita Rahmawati, Metode Pembelajaran Bahasa Asing, http://www. devita-rahmawati.blogspot.com/2012/01/metode-pembelajaran-bahasa-asing.html

Jauhar Ali, Pembelajaran Bahasa Arab Berbasis Cross Cultural Understanding, http://www. joebukan.blogspot.com. pembelajaranbahasa-arab-berbasis-cross.html

Lias Hasibuan, Kurikulum dan Pemikiran Pendidikan (Jakarta: Gaung Persada Press, 2010)

M. Asrori Ardiansyah, Konsep Inovasi Kurikulum, http://www.kabarpendidikan.blogspot.com. konsep-inovasi-kurikulum.html.

Mansur Muslich, KTSP (Dasar Pemahaman dan Pengembangan) (Jakarta: Bumi Aksara, 2008)

Muhbib Abdul Wahab, Epistemologi dan Metodologi Pembelajaran Bahasa Arab (Jakarta: UIN Syarif Hidayatullah, 2008)

Mulyasa, Implementasi Kurikulum Tingkat Satuan Pendidikan (Jakarta: Bumi Aksara, 2009)

Oemar Hamalik, Dasar-dasar Pengembangan Kurikulum (Bandung: Remaja Rosdakarya, 2008)

Rino, Strategi Implementasi KTSP, http://www.scribd.com/StrategiImplementasi-Kurikulum-Tingkat-Satuan-Pendidikan.html Suryo Subroto, Tata Laksana Kurikulum (Jakarta: Rineka Cipta, 2005) Tirman, "Pengembangan RPP”http://tirman.wordpress.com/ 
pengembangan-rpp/html.

Usman Alwin, Karakteristik KTSP, http://id.shvoong.com/social-sciences/education/2250517-karakteristik-ktsp/\#ixzz2MiqbSABY

Wina Sanjaya, Kurikulum dan Pembelajaran (Jakarta: Kencana, 2008) 